\title{
Ideal Concept of Progressive Law for Poor Convicts in Judicial Process Based on The Principles Of Constitutional Law
}

\author{
Zulkarnain Nasution \\ \{karnainnst@gmail.com\} \\ Doctor of Law, Universitas Jayabaya, Jakarta, Indonesia
}

\begin{abstract}
Judges' perception of the current law enforcement process is not yet based on progressive law, instead it is rather based on positivistic-legalistic legal thinking that views law merely a law that requires them to pursue legal certainty while neglecting the social justice. The concept of progressive law is essential in the law development, starting from the basic assumption that regards law an institution that aims to lead people to a just and prosperous life. This research is a normative legal research done using normative case studies. Statutory approach was employed, and data of this research were analyzed using an interactive model of analysis. It is found that judges in making decisions of legal cases involving poor defendants should also regard the progressive law and prioritize restorative justice. Imposing crimes through restorative justice for defendants living in poverty is the duty and responsibility of law enforcement officials to sharpen legal analysis and increase the sensitivity of the human conscience while at the same time maintain the ideal concept of providing legal aids in the judicial process for the poor is through penal mediation that can be carried out at court hearings, mediated by the judges. The legal basis for holding penal mediation at court level is the Law Number 4 of 2004 concerning Judicial Authority which contains the spirit of the restorative justice.
\end{abstract}

Keywords: Progressive Law, Defendant Living in Poverty, Penal Mediation, Restorative Justice

\section{Introduction}

Law enforcement in Indonesia consists of the police, prosecutors, lawyers, and judges. Among those four, the judge holds the most important role. This is because the judge can decide cases and determine who and what is right and wrong. A judge is a state judicial office authorized by law to adjudicate a matter before them [1]. The judge ultimately determines the verdict of a case based on the judge's intellectual, moral, and integrity towards the values of justice. Sometimes, judges are even seen as the personification of the law itself. They must guarantee a sense of justice for every justice seeker through the legal process in court [2].

Justice is one of the main objectives of law besides legal benefits and certainty [3]. According to Sudikno Mertokusumo, justice should cover the nature of justice and the content or norm to act concretely in certain circumstances. The nature of justice assesses treatment or action by examining it through a norm that subjectively exceeds other norms [4]. Meanwhile, Notohamidjodjo distinguishes justice into two types, creative justice (justitia creativa) and protective justice (justita protectiva). Creative justice grants everyone the freedom of justice to 
make something with their creativity, while protective justice is the sort of justice that provides shelter or protection to everyone in society [5].

The relationship between the law, the judges, and justice, which is also the manifestation of substantive justice based on the values of Pancasila, depends on the legal thinking applied by the judges in court. Thoughts of judges, in this case, must be based on progressive law, but the current reality reflects otherwise. The judge's belief in the process of enforcing the law has not yet adhered to progressive legal thinking. Instead, it is still based on the legalistic-positivistic position that views law only in the form of the constitution and only pursues legal certainty at the expense of people's sense of justice.

The progressive legal concept is vital in legal development. It was first introduced by Satjipto Rahardjo. Progressive law starts from the basic assumption that law aims to lead people to a just, prosperous, and happy life. Progressive law, in other words, is a law that envisions liberation in the way of thinking and acting upon the law. Hopefully, it enables the flow of law to complete its duties to humanity [6].

In establishing substantive justice, the judges apply progressive legal thinking with the method of legal discovery. Legal discovery is usually defined as the process of legal formation by judges or other legal officers who are assigned the task of implementing the law in concrete legal events. There are two schools in legal discovery, the progressive and conservative schools. Progressive schools argue that law and justice aim to prevent the degeneration of morals and other values [7]. Legal discovery has two types: interpretation and argumentum or argumentation. Interpretation is a method of legal discovery that provides a clear explanation of the legal text to determine the scope of the rule concerning a particular event. Argumentum or argumentation is a method of legal discovery used by judges that is similar to the relevant case being in question [8].

Guaranteeing justice for the justice-seeking community requires judges who possess good legal analysis skills, integrity, morals, and ethics. The judge, in this case, may not side with one of the parties in court. Judges in this regard are different from prosecutors who must side with the interests of the state and try to prove the defendant's guilt by reason for the sake of law and justice. However, consideration should also be directed to the insolvent defendant. These people deserve legal assistance as regulated in Article 27 of the Supreme Court Edict (Surat Edaran Mahkamah Agung - SEMA) Number 10 of 2010 concerning Guidelines for Providing Legal Aid. The law states that: "Those who are entitled to services from the Legal Aid Post are people who are unable to pay advocate services, especially women and children as well as persons with disabilities, following the prevailing statutory regulations." The provision of legal aid for eligible recipients is an effort to realize constitutional rights and implement a rule of law that recognizes, protects, and guarantees citizens' rights to the need for access to justice and equality before the law.

\section{Research Methods}

This research is normative law research which uses normative case studies by examining various laws and regulations. The focus of normative legal research is an inventory of positive law, legal principles, doctrines, and legal findings in concreto cases [9]. The approach method used in this research is the statutory approach with the data analysis model of an interactive model of analysis. 


\section{Results and Discussion}

The constitutional state term known in Indonesia is rechtsstaat and the rule of law. Notohamidjojo used the term rechtsstaat for a constitutional state [10]. Muhammad Yamin also equated the term rechtsstaat with legal state or government of law. According to Muhammad Yamin, the Republic of Indonesia is a constitutional state (rechtsstaat, government of law) where written justice prevails. Indonesia is not a police or military state, where police and soldiers hold government and justice, nor is it a power-state (machtsstaat) where weapons and a physical force acts arbitrarily [11]. Another legal expert, Sunaryati Hartono, defined rechtsstaat as a state that brings justice to all the people concerned. Here, the rule of law in a material sense is enforced [12].

The practice of legal injustice against the poor in Indonesia is still common. Law enforcement officers prioritize legal certainty and formal legality rather than legal justice, which is more substantial for the community. The law is played with and twisted, especially if it happens to be the case for the poor. In reality, law enforcement merely seeks formal truth and not substantial law when the poor face the law. Substantial laws are not laws that operate on legal articles but laws that operate in the dynamics of society.

The poor who are not knowledgeable of law must face law enforcement officials fluent in legal articles. The legal cases of Minah's grandmother and Asyani's grandmother are only a few examples of many poor people who have become victims of practices by law enforcement officials who disrupt the sense of justice in society. Researchers in this regard agree with Soetandyo Wignjosoebroto, who argues that in real life, the poor are often victims of unfair law enforcement. Law enforcement officials at the top of the social hierarchy consistently enforce control of the poor at the lower social strata.

This study uses restorative justice theory in analysing legal cases raised in this dissertation. In conventional criminal justice processes, there is something called restitution or compensation for victims. However, restoration has a deeper meaning than just compensation. Restoration means restoring the relationship between the victim and the perpetrator based on mutual agreement between the victim and the perpetrator. Victims can convey the losses they have suffered, and the perpetrator is allowed to make amends through compensation, peace, social work, or other agreements. This mechanism is important because the conventional justice process does not provide space for victims and perpetrators to solve problems actively. Regardless of its escalation, every indication of a criminal act will continue to be the affair of law enforcement and the jurisdiction of law enforcers, which eventually leads to a conviction.

Penal mediation can be conducted in a court session with the judge as to the mediator, especially considering justice and legal benefits. The legal basis for holding penal mediation is stated in Article 1 of Law Number 4 of 2004 concerning Judicial Powers. In this regard, the spirit of penal mediation is restorative justice.

Restorative justice is justice that applies in the non-litigation dispute resolution process or known as Alternative Dispute Resolution (ADR). The purpose of the restorative justice approach is to reach an agreement on the best solution to resolve conflicts. Restorative justice is a new way of looking at criminal justice that focuses on repairing the damage that afflicted victims and restoring rapport rather than punishing the perpetrators of criminal acts. As represented by law enforcement institutions, the state does not take over the resolution of conflicts because restorative justice does not see a crime as something against the state but against the members of the community who are collectively referred to as victims.

This paper argues that it is necessary to apply restorative justice as a form of legal alignment for the poor in some instances. The state must seek alternative criminal acts amid the 
phenomenon of legal injustice that befell the poor. The appropriateness in criminalization through restorative justice is the duty and responsibility of law enforcement officials to sharpen their legal analysis and increase their sense of the human conscience. Restorative justice can be a means of equitable justice, especially for victims and parties who are socially and politically vulnerable and economically weak, including the poor. Therefore, positive law in Indonesia must be able to cope with the existence of restorative justice.

Assurance of the constitutional right to legal aid for the poor has not been appropriately considered until Law Number 16 of 2011 concerning Legal Aid. The four criteria for people qualified for free legal assistance must truly refer to the provisions in Article 5 paragraph (1) of Law Number 16 of 2011 concerning Legal Aid, that the person receiving legal assistance is any person or group who is abjectly poor, as evidenced by the conditions that have been proven. The state recognizes the existence of economic, social, cultural, civil, and political rights for the poor, and therefore based on constitutional rights, they have the right to be represented and defended by both inside and outside the court (access to legal counsel). Thus, legal aid is the right of poor people without payment (pro bono publico) in this sense is the translation of equal rights before the law.

Additionally, there is also legal assistance to suspects at the pre-adjudication level. The pre-adjudication stage is the initial process for the investigator to determine whether an incident is a criminal act or not and find evidence to arrest a suspect. Then, there is legal assistance to the defendant during the adjudication process. The adjudication stage is an advanced stage from the pre-adjudication stage, by which the defendant proceeds to be prosecuted by the Public Prosecutor (Jaksa Penuntut Umum-JPU). Law enforcement officials must optimize the provision of legal aid for the poor for better legal access and assurance of justice for the poor. Apart from being advocates, judges can provide legal assistance for the poor. This is because judges play a crucial role in the Criminal Justice System (Sistem Peradilan Pidana-SPP) in Indonesia.

\section{Conclusion}

A judge in deciding legal cases for the poor should have a progressive view and prioritize restorative justice. Imposing crimes through restorative justice for the poor is the duty and responsibility of law enforcement officials to sharpen legal analysis and increase the sensitivity of the human conscience. Besides that, the ideal concept of providing legal aid in the judicial process for the poor is through penal mediation that can be carried out at court hearings with the judge as to the mediator. The legal basis for holding penal mediation at the court level is Law Number 4 of 2004 concerning Judicial Power with restorative justice as its spirit of penal mediation.

\section{References}

[1] Ahmad Rifai, Penemuan Hukum oleh Hakim dalam Perspektif Hukum Progresif, (Jakarta : Sinar Grafika, 2010).

[2] H. Ahmad Kamil, Filsafat Kebebasan Hakim, (Jakarta : Kencana, 2012),

[3] Achmad Ali, Menguak Tabir Hukum - Suatu Kajian Filosofis dan Sosiologis, (Jakarta: Gunung Agung, 2002),

[4] Sudikno Mertokusumo, Mengenal Hukum, (Yogyakarta : Liberty) 
[5] Bayu Setiawan, Penerapan Hukum Progresif oleh Hakim untuk Mewujudkan Keadilan Substantif Transedensi, Jurnal Kosmik Hukum Vol. 18, No. 1, Januari 2018.

[6] Sudjito, Hukum dalam Pelangi Kehidupan, (Yogyakarta : Gadjah Mada University Press, 2012).

[7] Abdulkadir Muhammad, Hukum dan Penelitian Hukum, Cetakan I, (Bandung : Citra Aditya Bakti, 2004).

[8] O. Notohamidjojo, Makna Negara Hukum, (Jakarta : Badan Penerbit Kristen, 1970.

[9] Muhammad Yamin, Proklamasi dan Konstitusi, (Jakarta : Ghalia Indonesia, 1982).

[10] Sunaryati Hartono, Apakah The Rule of Law, (Bandung : Alumni, 1976). 